\title{
The Role of Political Divestiture for Sustainable Development
}

\author{
Julia M. Puaschunder ${ }^{1}$ \\ ${ }^{1}$ Department of Economics, Schwartz Center for Economic Policy Analysis, New School for Social Research, \\ New York, USA \\ Corresponding: Julia M. Puaschunder, Department of Economics, Schwartz Center for Economic Policy \\ Analysis, The New School for Social Research. 1129F-99, 11th floor, 16th Street, 6 East, New York, USA. \\ E-mail: Julia.Puaschunder@newschool.edu
}

\author{
Received: January 1, 2016 \\ Accepted: January 27, 2016 Online Published: February 25, 2016 \\ doi:10.5539/jms.v6n1p76 \\ URL: http://dx.doi.org/10.5539/jms.v6n1p76
}

\begin{abstract}
In the wake of historical and political events, stakeholder pressure can trigger shareholders to divest from politically incorrect markets with the goal of accomplishing socio-political change. While mainstream development research advocates for more private investor involvement in sustainable development to achieve the Sustainable Development Goals (SDG)s in funding infrastructure, health, education and climate change mitigation; the following paper introduces political divestiture as an alternative means to implement sustainable development. While foreign investment can create positive conditions for improving societal development, also politically incorrect usage of funds or regulatory lacunae can do harm in the developing world. Political divestiture is portrayed as an innovative investment allocation to maximize positive development impacts of investment whilst minimizing associated risks of politically insecure markets. In an attempt to balance risk and access to capital, political divestiture is proposed as a means to implement sustainable development by removing funds from politically incorrect regimes in order to be channeled towards socially responsible and sustainable finance solutions. Future research outlooks on political divestiture as sustainable development driver comprise the antecedents and success factors as well as institutional and international frameworks to foster Financial Social Responsibility in the long-term international development domain.
\end{abstract}

Keywords: business ethics, financial social responsibility, political divestiture, Socially Responsible Investment (SRI), sustainable development, United Nations

\section{Introduction}

We live in the "Age of Responsibility" in the "Era of Re-Orientation" since the 2008 World Financial Crisis (World Investment Report, 2015; Zoellick, 2009). Globalization, political changes and societal trends, but also the current state of the world economy, have leveraged a societal demand for ingraining responsibility into market systems. Today social responsibility has emerged into an en vogue topic for the corporate world and the finance sector.

With globalization featuring the progressive deterritorialization of social, political, economic interaction concurrently raises societal concerns beyond the power, control and influence of national governments. In a globally interlinked world, governmental agencies' ability to protect citizenship rights, fulfil social obligations and avert global crises gradually declines and imposes the demand for social responsibility onto corporate actors. Globalization shifts national governments' obligations to international governance solutions in the corporate world (Panitch \& Gindin, 2012). As multilayered economic systems are structured by the strategic coordination of international corporate entities, corporate multinationals nowadays have turned to solve global societal crises beyond the control of singular nation states.

In addition, access to information revolutions in the Western World have steered attention to corporate ethicality. In the digital age, most pressing societal problems have become blatant through information provided to widespread international stakeholders. Heightened transparency makes corporate conduct and governmental actions visible to a broad range of constituents. As the IT revolution provides increasing degrees of easily-accessible information, corporate societal impacts become subject to scrutiny to an affluent, internationally-focused "Weltgesellschaft" who demand respect for social business ethics around the globe (Nelson, 2004; Werther \& Chandler, 2006; Zoellick, 2009). The emergence of NGOs further contributes to 
corporate conduct disclosure and the integration of social responsibility into corporate practices.

As for these trends, multinational corporate conduct currently exhibits higher levels of responsibility vis-à-vis society. With trends predicting continuing globalization and corporate conduct disclosure and crises beyond the control of single nation states emerging, the demand for corporate and financial social responsibilities is continuous predicted to increase (Beck, 1998; Bekefi, 2006; Centeno \& Tham, 2012; Fitzgerald \& Cormack, 2007; Scholte, 2000). Today's most pressing societal long-term downfalls call for corporate social activities to back governmental regulation to steer sustainable development (Puaschunder, 2015c). Sustainable development goals pay attention to the conservation of natural resources, environmental protection and societal well-being. Holding widespread access to vital economic resources and markets, contemporary multinationals have become quasi-global governance institutions and implicit political authorities to regulate economic activity in the architecture of the world economy.

Concurrent with corporations having started to pay attention to social responsibility, ethical considerations have become part of the finance world. The global financial and economic crises that broke out in September 2008 emphasized the importance of solid regulatory frameworks for investments (World Investment Report, 2015). In the aftermath of the 2008 financial crisis, the call for social responsibility in the finance sector has reached unprecedented momentum (Puaschunder, 2011a; 2015c). The renaissance of attention to responsibility as a prerequisite for the functioning of economic systems makes a socially conscientious finance sector appear as windows of opportunity to steer societal progress alongside sustainable development (Little, 2008; Livesey, 2002; Matten \& Crane, 2005; Puaschunder, 2015b; Trevino \& Nelson, 2004). Recent concerns about the strength and conduct of individual foreign investors have brought foreign investment under scrutiny (World Investment Report, 2015). Increasingly, investment behavior is assessed on whether it complies with international standards, such as the UN Guiding Principles on Business and Human Rights, the revised OECD Guidelines on Multinational Enterprises, and the FAO/World Bank/UNCTAD/IFID Principles on Responsible Agricultural Investment (PRAI). NAFTA investment agreements oblige investment protection and liberalization objectives must not be pursued at the expense of the protection of health, safety, the environment and the promotion of internationally recognized human rights standards (World Investment Report, 2015). In addition to standards developed by international organizations, investors are expected to report on their consideration of CSR in their portfolio choice. With the emerging stream of literature on sustainable development, the finance community concurrently started paying attention to ethical considerations of asset-issuing entities (Little, 2008). The finance community set out to portray how investments can become part of the broader socio-economic development agenda in aiding sustainable development goals (Little, 2008; World Investment Report, 2015). Worldwide regulatory standards are aimed at improving the investment climate by promoting the rule of law and enhancing good governance in finance. Canada and the United States have incorporated proceedings such as open hearings, publication of related legal documentation and the possibility for related stakeholders to submit amicus curiae briefs to tribunals (World Investment Report, 2015). Contemporary finance ethics has become a prominent term in sustainable development (The Wall Street Journal, August 21, 2008; Zoellick, 2009). The importance of financial markets in international development has been paid tribute by the 2006 Nobel Peace Price awarded to Muhammad Yunus and the Grameen Bank for creating socially attentive banking systems. In the wake of the micro-finance revolution, SRI has been advocated for in the World Economic Forum 2009 and found expression in public advocacy in the United Nations Principles for Responsible Investment (UN PRI) (Ahmad, 2008).

Developing an interest in corporate social conduct, conscientious investors nowadays fund socially responsible corporations (Sparkes, 2002; The Wall Street Journal, August 21, 2008). The consideration of CSR in investment decisions is the basis for Socially Responsible Investment (SRI)-an asset allocation style, in which securities are not only selected for their expected yield and volatility, but foremost for social, environmental and institutional aspects. Pursuing economic and social value maximization alike, socially conscientious investors fund socially responsible corporations based on evaluations of the CSR performance as well as social and environmental risks of corporate conduct. Thereby SRI becomes an investment philosophy that combines profit maximization with intrinsic socio-economic components allowing the pursuit of financial goals while catalyzing positive societal change (Matten \& Crane, 2005; Mohr, Webb, \& Harris, 2001). SRI securities are thereby not only selected for their expected yield and volatility, but also for social, environmental and institutional aspects (Livesey, 2002; Schueth, 2008; Wolff, 2002).

The most common forms to align financial investments with ethical, moral and social facets are socially responsible screenings, shareholder advocacy, community investing and social venture capital funding. Financial investment strategies are coupled with political activism in the case of political divestiture, which refers to the removal of investment from socially irresponsible markets following the greater goal of accomplishing 
socio-political changes. By Foreign Direct Investment (FDI) flows, socially responsible investors refrain from contributing to politically incorrect market regimes in order to address global governance goals (Schueth, 2008; Starr, 2008). Divestiture is common to steer change in politically incorrect regimes, but can also contribute to international political development in promoting environmental protection, human rights, working conditions, animal protection, safety and health standards (Broadhurst, Watson, \& Marshall, 2003; Harvey, 2008; McWilliams, Siegel, \& Teoh, 1999). Apart from the traditional political divestiture as the strategic investment capital drain from politically incorrect markets, political divestiture in combination with positive screening techniques can therefore also directly contribute to socio-political betterment and close policy gaps. This investor statement can direct impact local, national and international policies in various domains such as trade, labor, social issues, taxation, intellectual property, land rights, security, cultural policies, health and environmental protection (World Investment Report, 2015).

Given the rising demand of social responsibility within market systems, the common body of knowledge on SRI is fairly limited. Empirical studies on SRI are rare with the current body of research primarily targeting at efficiency and financial correlates of SRI. While market studies foremost focus on economic fundamentals, the knowledge on political components of socially responsible financial decision making is scarce. In the given body of descriptive literature tracing back the emergence of SRI to a combination of historical incidents, legislative compulsion and stakeholder pressure, our insights on socially responsible investors' impact on political outcomes and our knowledge on the role of financial markets to drive sustainable development by positive investment streams is limited (Puaschunder, 2011b, 2015d). In addition, until today the rise of SRI as a political sustainable development success factor is unexplained. In the given literature on sustainable development in the corporate sector and contemporary CSR models, political divestiture appears to have been neglected. While the notion of sustainability has been integrated in CSR models, political divestiture has hardly been touched on as for being a more financial and economic case for codifying the triple bottom line.

In the already scarce literature on political divestiture, capital flight's impacts on sustainable development have been neglected. While corporations seem to spend much energy on divestiture strategies, little effort seems to be dedicated to analyzing the outcome of corporate withdrawals on markets and society (Grunberg, 1981; Harrigan, 1981). Consequently, to date no stringent pattern of political divestiture and sustainable development impacts has emerged (Dittmar \& Shivdasani, 2003; McWilliams \& Siegel, 2000; Puaschunder, 2013; Zeff \& Pirro, 1999).

Advocating for integrating political concerns in CSR models in academia and practice, however, holds untapped advantages of economically influential corporate entities contributing to sustainable development. Integrating a political dimension in contemporary sustainable development helps imbuing a longer-term perspective into the finance world alongside advancing international development and global governance crises prevention. Shedding light on the potential of directing capital flows from politically dangerous volatile markets to places where sustainable development may be accomplished with funding holds valuable information for the international investment community as well as global governance advocates. Understanding the impacts of political divestiture in a financially globalizing world is important as FDIs has untapped potential to complement traditional foreign policies. Foreign capital drain has proved to be an efficient and unbureaucratic way to undermine socio-politically incorrect regimes without resorting to warfare or direct sanctions. In this light political divestiture appears to be an effective approach for strategic global governance, yet many aspects of financial withdrawal to pressurize governments have not been clarified sufficiently.

Overall describing political divestiture helps resolving societal losses imbued in the novelty, complexity and ambiguity of Financial Social Responsibility. Evaluating up-to-date research on how financial social consideration will increase the effectiveness of SRI as a political instrument to the finance community. Gaining a more sophisticated understanding of the finance community's role in sustainable development will help finding repeatable patterns and crafting policies to strengthen SRI's impetus on sustainable development within financial markets. Research on political divestiture in the age of responsibility will help understanding SRI as a means to establish sustainable development in financial global governance to ensure financial market stability as a prerequisite for sustainable market economies and future guarantee of societal progress. Contributing to a successful rise of social responsibility within modern market economies is aimed at SRI becoming a mainstream feature of financial decision making serving the greater goal of fostering positive societal change.

The following chapter therefore promotes the idea of political divestiture as an alternative to national governance and novel extension of contemporary sustainable development goal accomplishment mechanisms. Underlying the idea that corporate executives have an obligation to consider sustainable development, the following chapter theoretically highlights the finance world's potential to accomplish current sustainable development goals and explores sustainable development implementation strategies of the finance world. The first part introduces the 
concept of political divestiture in order to prepare for the following analysis of the impact of divestiture on sustainable development. In an attempt to investigate financial markets' potential to steer societal and political change, the current body of knowledge on and state-of-the-art of political divestiture will become subject to scrutiny. Generalizing insights on the effectiveness of political divestiture in accomplishing sustainable development goals will help deriving success factors of investment focus on societal advancement. Analyzing welfare effects of political divestiture will provide valuable guidance for corporate, financial and public decision makers. Knowledge about the effectiveness of political divestiture will also help in the generation of public policies for institutional assistance in fostering political divestiture as a means of sustainable development.

\section{Political Divestiture}

In recent decades, SRI experienced a qualitative and quantitative growth in the Western World. As of today shareholder activism has been adopted by a growing proportion of investors around the world to exert activist influence ranging from political lobbying, consumer boycotts and confrontations geared by negative publicity to pressure corporations into socially responsible corporate conduct (Sparkes \& Cowton, 2004). Parties engaging in shareholder dialogues seek to influence corporate policies and practices without introducing a formal resolution on their concerns. The influence of financial markets in global governance becomes apparent in the capital withdrawal from politically incorrect markets (Steurer, 2010).

Political divestiture targets at forcing political change by imposing financial constraints onto politically incorrect regimes that counterpart from international law resulting in war, social conflict, terrorism and human rights violations. Removing stocks from a portfolio to screen out socially irresponsible corporations based on social, ethical and religious objections follows the greater goal of accomplishing social and political change (McWilliams \& Siegel, 2000). In the case of political divestiture, investments are withdrawn from politically incorrect markets in the wake of stakeholder pressure and global governance sanctions economically pressuring coercive regimes and governments that depart from international law and human rights standards. Political divestiture shareholder action is an anti-war alternative to steer governmental reforms that evolved in the wake of stakeholder activism against socio-political inhumanities (Alperson, Tepper-Marlin, Schorsch, \& Wil, 1991; Bekefi, 2006; Kanter, 2003; McWilliams \& Siegel, 2000). Positive political and societal change is triggered by economic trade restrictions and sanctions alongside cultural embargos (Merriam Webster Dictionary, 2008). First discussed in the case of the Angolan repressive regime, political divestiture has been practiced to undermine warfare (e.g., the Israel-Palestine conflict), terrorism (e.g., Afghanistan), nuclear proliferation and power accumulation (e.g., Iran), social infringements and human rights violations-such as genocide in the Sudanese Darfur region (Schueth, 2008; Starr, 2008; Williams, 2005). One of the most powerful and visible political divestiture acts in history was the capital flight from South Africa during Apartheid. Additional cases are FDI withdrawals of governmental human rights violations in Burma as well as the current humanitarian crises in Sudan's Darfur region.

While empirical investigations of the relationship between SRI and profitability offer no generalizable pattern (Butz, 2003; Hamilton, Hoje, \& Statman, 1993; McWilliams \& Siegel, 2000) and up to date there are no stringent answers on political divestiture's relation to the overall market performance (Dixon, 2002; Jones, van der Laan, Frost, \& Loftus, 2008; Little, 2008; Mackey, Mackey, \& Barney, 2004); political divestiture allows corporations to reduce socio-political and image loss risks. Data on the profitability of political divestiture indicates a potential first mover advantage for early divestiture. In a cost and benefit analysis, SRI implies short-term expenditures, but grants long-term sustainable investment streams. Positively screened SRI funds - that more likely feature IT-technology and alternative energy industries attracting innovative venture capital - tend to be more volatile, yet if successful, grant high profitability-e.g., solar energy funds have significantly outperformed the market in recent years and remained relatively stable during the 2008/09 World Financial Crisis. As for excluding high-return, high-volatility industries such as petroleum, defense and addictive substances, negatively screened options are more likely to underperform in the market. At the same time negative screened market options are robust to overall market changes. Negative screening asset holders are more loyal to their choice in times of crises, which contributes to the stability of these options. In the short run, screened funds have a higher expense ratio in comparison to unscreened ones - that is social responsibility imposes an instantaneous 'ethical penalty' of decreased immediate shareholder revenue (Mohr \& Webb, 2005; Tippet, 2001). However, searching for information and learning about CSR as well as the act of divestiture is associated with cognitive costs. Screening requires an extra analytical decision making step-especially positive screens are believed to be more cognitively intensive than negative ones (Little, 2008). In addition, screening out financial options lowers the degrees of freedom of a full-choice market spectrum and risk diversification possibilities (Biller, 2007; Williams, 2005). 
Counterparting the up-to-date notion of political divestiture being solely focused on foreign investment drain, the role of political divestiture for sustainable development may be explored in the following in describing the strategic political divestiture act to avoid highly-volatile politically risky markets and channel funds towards market-outperforming socially conscientious and sustainable market options fostering sustainable development and societal advancement. Political divestiture for sustainable development can thereby 'do good' whilst avoiding risky markets 'doing harm' to society. Ethically-guided investment flows that reduce political risks and steer social good also signal a more stable ethical investment climate to the overall market.

\section{Political Divestiture for Sustainable Development}

The age of globalization heralded the call for international responsible leadership (Puaschunder, 2015a). The general demand for fairness led to the inception and subsequent adoption of Sustainable Development Goals (SDG)s in the corporate world. The quest for an integration of the finance sector in contemporary sustainable development models of capitalism in the 21 st century is targeted at strengthening socially responsible economic market approaches. Acknowledging the untapped potential of the finance sector to address global challenges beyond the reach of singular nation states, calls for the integration of sustainable development in political divestiture decision making. Political divestiture thereby seems as financial market alternative to help alleviating current sustainable development predicaments and avert future predictable economic, social and environmental crises.

In recent decades, political divestiture has increasingly become an element of fiduciary duty, particularly for investors with long-term horizons that oversee international portfolios. The ascent SRI has been accompanied by a change in the qualitative nature of social investments. The current SRI notion is very different from the earlier 'ethical investment' based on negative screenings (McCann, Solomon, \& Solomon, 2003). Although a moral touch remains, the establishment of SRI retail funds and the adoption of SRI by institutional investors have turned SRI into a pro-active positive screening of sustainable financial market options. As for these trends, political divestiture has come closer to serving sustainable development.

Sustainable investment is needed in global economic growth and development, especially in light of financing SDGs and developing countries being highly dependent on corporate contributions, which emerge from multinational enterprises building their corporate structures through cross-border investment and financial investors allocating funds sustainably. There are massive worldwide financing needs for sustainable development and FDI plays a crucial role in bridging the investment gap, especially in developing countries. Due to stability and diverse development impact compared with other sources of finance, FDI is the most important component of external development finance to fragile economies. Over the past decade, FDI stock tripled in least developed countries and small-island developing economies and quadrupled in landlocked developing countries. At the same time, inward FDI to the developing economics reached their highest level at USD 681 billion with a 2 percent rise in 2015 (World Investment Report, 2015). Developing countries extended their global lead with China becoming the world's largest recipient of FDI. Among the top 10 FDI recipients in the world, 5 are developing economies. FDI inflows to Africa remained flat at USD 54 billion, while the developing Asia saw FDI inflows grew to historically high levels up 9 percent. FDI flows to small island developing countries increased by 22 percent and landlocked developing countries saw a decrease of 2.8 percent. FDI flows to structurally weak, vulnerable and small economies increased by 3 percent to $\$ 52$ billion (World Investment Report 2015).

According to the World Investment Report 2015, investment community trends will still be geared towards investment liberalization, promotion and facilitation in the future. Global FDI flows are expected to reach $\$ 1.4$ trillion in 2015, an 11 percent rise. Flows are expected to increase further to $\$ 1.5$ trillion and $\$ 1.7$ trillion in 2016 and 2017 (World Investment Report, 2015). With a concerted effort by the international investment development community, FDI in weak economics could quadruple by 2030. In the future, economic diversification should target at fostering greater sustainability in these most vulnerable countries (World Investment Report, 2015). While an increasing FDI pattern towards the developing world can be noticed, increasing the quantity of funds must be coupled with improving the quality of channeling, paying attention to the extent to which investment delivers concrete sustainable development benefits (World Investment Report, 2015).

While there is a trend towards FDI's increasing role in sustainable finance and societal advancement, investment measures for sustainable development are limited. Only 8 percent of measures between 2010 and 2014 were specifically targeted at private sector participation in key sustainable development sectors of infrastructure, health, education and climate stability. In the research on how to close the SDG investment gap and channel investment into key sectors for sustainable development, the role of political financial divestiture for sustainable 
development remains an open research question.

The general notion is that profit shifting out of developing countries can have a significant negative impact on their prospects for sustainable development. The international investment and development community should therefore build a common framework for global investment cooperation for the benefit of the developing world (World Investment Report, 2015). Better governance and greater coherence to manage the interaction between international tax and investment policies, not only avoiding conflict between the regimes but also making them mutually supportive is essential.

From a global governance perspective, the UN plays a pivotal role in promoting SRI in initiatives and financial political actions. On the global level, the Conference on Financing for Development led to the Monterrey Consensus of 2002, a pledge by participants to mobilize financial assistance for developing economies and international financial for structurally weak, vulnerable and small economies in order to ensure robust, resilient growth and sustainable development.

In January 2004, the UN advocated for the financial sector meeting the United Nations Global Compact (UNGC)'s objectives. Subsequently a group of leading financial institutions were invited to form a joint financial sector initiative under the guidance of the UNGC Board. In associated research units, the initiative developed guidelines and recommendations on how to integrate environmental, social and corporate governance in asset management and securities brokerage services. In February 2008, the UN Conference on Trade and Development (UNCTAD) launched the 'Responsible Investment in Emerging Markets' initiative, which enhances transparency of emerging financial markets. This public private partnership targets at fostering transparency and disclosure of emerging financial markets. The United Nations Global Compact division leads the international public administration of Financial Social Responsibility in the 'The Principles for Responsible Investment' (PRI) launched at the New York Stock Exchange in April 2006. The UN Principles for Responsible Investment (PRI) encourage institutional investors to embrace SRI. This initiative develops guidelines and recommendations on how to integrate environmental, social and corporate governance in financial markets and how financial investment banks and fiduciaries can implement social responsibility goals as a risk management tool. The PRI are supported by the UNGC Conference Board, the chief executive officers of 20 global corporations, the International Finance Corporation of the World Bank Group, the Swiss Government, Columbia University and the United Nations Environment Programme (UNEP) Finance Initiative. Under the auspice of the UNGC and the UNEP Finance Initiative, the PRI invite institutional investors to consider SRI and mobilize chief executive officers of the world's largest pension funds to advance SRI on an international level. The principles are designed to place Financial Social Responsibility into the core of investment decision making of financial managers and asset owners of pension funds, foundation assets and institutional endowments. At the one-year anniversary of the PRI, more than 170 institutions representing approximately US \$ eight trillion in assets had committed to the PRI. In the international arena, the UN Global Compact has raised over 10,000 members in 2000, including over 7,000 businesses in 145 countries around the world (Puaschunder, 2010). Increasing and expanding CSR initiatives indicate that more and more business leaders commit their companies to contribute to the "triple bottom line" to harmoniously considers social, environmental, and economic sustainability in every day corporate decision making (Elkington, 1997). Respect for 'people, planet, and profits' has become a corporate necessity and industrial imperative. Corporate sustainability and social responsibility has thus emerged to unprecedented momentum in academia and practitioners' discourse.

Today business leaders tend to contribute to the creation of economic and societal progress in a globally responsible and sustainable way by means as never before experienced. Corporations that join the PRI report concomitant tangible (profit gain, efficiency, product innovations, market segmentation) and intangible (reputation, employee morale) benefits. The United Nations Environment Programme Finance Initiative (UNEP FI), the Equator Principles, The Green Bond Principles and the various corporate reporting lead initiatives such as Global Reporting Initiative (GRI) and Integrating Reporting (IR) are additional UN responsible investment activities. The key constituents are stock exchange and financial analyst communities as future SRI drivers to support the UNGC goals. In addition, NGOs are invited to advance financial market transparency and accountability. For the future the world's leading Stock Exchange Commissions seek to further support the PRI and consider innovative ways how to partner with the UNGC. Sustainable development impact reporting can thereby highlight sustainable development criteria such as environment and social standards. For instance, the United States' Overseas Private Investment Corporation (OPIC) uses about 30 development indicators to evaluate job creation and human capacity-building, sustainability effects as well as impacts on environmental and community benefits (World Investment Report, 2015). In addition specific sustainable development outcomes could be screened if being in line with industrial development strategies and regional economic 
cooperation. Future monitoring could comprise of an ombudsperson and facilitator to help ensure a vital sustainability climate.

In light of the rising climate change awareness and demand for an economically efficient transitioning into renewable energy, the UN-led Earth League most recently incepted the Climate Risk and the Finance Sector working group in partnership with United Nations Environment Programme Finance Initiative (UNEP FI), the World Resources Institute (WRI), and the Global Challenges Foundation. The UNEP FI is a global partnership between the UNEP and the financial sector. Over 200 institutions, including banks, insurers and fund managers, work together with UNEP to capture the mutual impacts of environmental and social considerations on financial performance.

At the 3rd Conference on Financing for Development in July 2015 in Addis Ababa, and at the global summit on the Sustainable Development Goals in New York City in September 2015, external financing for development was proven as key driver of developing economies. In the wake of the 2015 inception of the UN Sustainable Development Goals, a report was published by UNEP FI in cooperation with the PRI, UNEP Inquire and the UNGC that aims at elucidating debates surrounding environmental, social and governance issues in the light of fiduciary duty. The report is meant to foster investors' understanding and consideration of environmental, social and governance (ESG) issues in their investment decision making. The research stresses the point that a failure to consider long-term investment value drivers including ESG issues in investment practices is a failure of fiduciary duty. The report also touches on the implementation of sustainable finance and impact investment in order to propose practical action for institutional investors, financial professionals and policy-makers to embrace sustainable development.

Given the pressing demand for sustainable development, the need for an introduction of political divestiture as a means to implement the sustainable development goals is blatant. In a climate of corporate governance and global challenges beyond the control of singular nation states, the idea of promoting political divestiture as a sustainable development incentive and conditionalities tool has reached unprecedented momentum. Departing from narrow-minded, outdated views of responsibilities of corporations only adherent to making profit for shareholders and abiding by the law (Friedman, 1970); corporate executives nowadays are more prone to act responsibly in meeting the needs of a wide range of constituents. Apart from avoiding unethical societally harmful behavior, such as bribery, fraud and employment discrimination, corporate executives currently pro-actively engage in corporate governance practice with a wider constituency outlook, including the needs of future generations.

What are potential obstacles of political divestiture leading to sustainable development? Regulations appear to be lagging behind when considering novel challenges in the eye of interdependent economic, institutional and political networks determining financial market moves. New risks are imposed onto corporate and financial actors by fast-paced information flows that increase the complexity of decision making contexts and the cognitive overload of fallible financial leaders.

As a remedy, sustainable development leadership is called for that steers intentional finance executives' actions to benefit the stakeholders and should-do care for political concerns alongside financial considerations. As a broader definition of corporate responsibility beyond avoidance of negative downfalls, the call for political divestiture as a sustainable development implementation tool in the corporate world encompasses the obligation to not only withdraw funds from politically incorrect regimes but to contribute the newly released fund towards options that steer societal progress with respect for the needs of future generations. Not simply considering to avoid unethical behavior by political divestiture, but also adopting a positive and pro-active ethics lens through green investments, sustainable development leadership in the finance world will become an ueberethical drive to consider the interests of a wider range of stakeholders (Puaschunder, 2012, 2015a). Sustainability concerns of the finance world thereby directly reach out to a wider constituency group. Stretching the constituency attention to future generations is based on a voluntary sustainability with respect for future generations' needs to ensure the long-term viability of society. Surpassing state-of-the-art ethical corporate leadership quests on ethically compliant behavior and avoidance of unethical corporate conduct, incorporating sustainable development into contemporary SRI models may elevate the idea of 'positive political divestiture' - that is outdoing legal and ethical expectations-with respect for UN sustainable development goals. Going beyond mere compliance involves actions that pro-actively promote social good, beyond what is required by law, political divestiture for sustainable development leverages SRI as a broader social contract between business and society over time. Financial leadership on sustainable development should thereby extend social responsibility beyond compliance and encompasses the wider obligation to contribute to societal progress in a responsible and sustainable way. Defining novel responsibilities with a broader social contract between finance and society embraces 
discretionary activities that contribute to sustainable societal welfare thereby provides a broad range of corporate, social and societal advantages.

Socially responsible funds offer crisis-stable market options, as being less volatile and influenced by cyclical changes and whimsical market movements. Especially negative screenings are extremely robust in times of uncertainty - as socially conscientious investors remain loyal to values (McLachlan \& Gardner, 2004; Puaschunder, 2011b). As for this track-record of stability during times of societal and economic downturns, political divestiture nowadays appears as a favorable market strategy for lowering emergent risks and ingrain sustainability in economic market systems (Centeno \& Tham, 2013; Puaschunder, forthcoming).

\section{Future Perspectives}

Globalization has placed social and environmental concerns on financial managerial agendas to an increased extent while more and more financial managers operate in a global environment. The future conceptualization of sustainable and responsible managerial behavior may embrace the wider constituency range and stretch the concept of political divestiture from FDI withdrawal to pro-active voluntary sustainable development funding. An extended stakeholder view on political divestiture may not only stop at funds withdrawal but consider a broader set of constituencies. Future targets in financial decision making may impact on the social performance and long-term viability of society.

A broader, social contract between finance and sustainable development can be enacted by discretionary activities that are not expected of the finance world and their leaders in a moral or legal sense but directly contribute to sustainable development. This suggests that there is a need for a broader definition of Financial Social Responsibility that goes beyond compliance and in particular political divestiture to encompass the obligation to contribute to societal progress in a responsible and sustainable way. Finance leaders thereby pro-actively outperform legal and ethical expectations regarding the rights and needs of future generations. This positive CSR drive refers to an ueberethical enhancement of societal welfare beyond the narrow scope of the current generation (Puaschunder, 2012).

In the age of globalization, multidisciplinary and multilevel research approaches may investigate the comparative and cross-national dimensions of political divestiture and their implications for leadership decision making and behavior in the global arena. Interdisciplinary and multilevel research approaches could feature scientific collaborations with researchers based in different countries to embark on contemporary political divestiture studies and investigate the comparative and cross-national dimensions of political divestiture impacting corporations, economic markets as well as society (Puaschunder, 2015b). Sustainability development representing agents from different disciplinary backgrounds (economics, business, psychology, etc.), research fields (e.g., strategy, organizational behavior, and international and cross-cultural management within the field of business), methodological approaches (both qualitative and quantitative), and regional expertise (in-depth knowledge of North-American, European, and Asian business systems and institutional environments) may engage on the description of political divestiture as a pro-active finance choice that does not rest at 'punishing' politically incorrect markets but rather promotes political divestiture as sustainable development tool to create positive societal change.

International studies of financial world investment reports should be targeted at deriving a sophisticated conceptualization of 'responsible behavior' in the political divestiture domain that is applicable to all cultural groups and stakeholders. International research on political divestiture could unravel drivers of sustainable development responsible financial managerial behavior. Cross-national, multi-level analyses could thereby retrieve influence factors on the adoption of globally responsible SRI and financial practices that trigger sustainable development. Knowledge of contextual factors that promote political divestiture decision-making with regard to sustainability could include favorable characteristics of the organization and aspects of the broader institutional and cultural contexts in which firms are embedded that automatically trigger sustainable development concern. Thereby the antecedents of sustainable and responsible management at multiple levels (individual, group, organization, national context, supranational bodies) but also the interlinkages among variables should be investigated.

Institutional contexts within which companies and their managers operate determine executives' responsible choices. Differences in corporate governance and legal contexts but also the nature of regulation and the likelihood of enforcement shape business ethics as well as expectations of what is considered good governance and ethical conduct in a country. Managers' responsible leadership may therefore vary across institutional contexts in the international arena. What may be considered as political practice in one part of the world may not be ethical state-of-the-art in another. As a consequence, corporate leaders embedded in different national systems 
may exhibit different political concerns and sustainable development standards. Cross-national variations in political practices and socially responsible divestiture could be captured in order to derive implications for financial decision-makers on how their political divestiture activities could steer sustainable development. Adopted SRI strategies and political divestiture cases may be scrutinized for globally standardized, locally adapted, and transnational factors to delineate globally consistent as well as locally-oriented political divestiture approaches to support sustainable development.

With the underlying premises of exhibited behavior being a function of both the person and the environment in which that behavior takes place, future research may also unravel political divestiture under situational constraints that the broader cultural and institutional environment impose on the adoption of sustainable and socially responsible practices. Cross-culturally operating institutions may face challenges for political divestiture stemming from local differences in financial practices and social ethical norms as well as differing thresholds to sustainable behavior. For instance, challenges arise if corporations or even nation states of the industrialized world outsource financial decision making or sustainable development practices into territories with weaker law enforcement and public scrutiny. These findings emphasize the need for sensitivity to local conditions, transparency of financial decision making as well as stakeholder expectations monitoring when conducting business in different contexts. Future research may also address ethical dilemmas faced by financial managers in the global arena and their coping strategies in order to enhance leaders' potential on international political divestiture and sustainable development practices, which should be locally-oriented and emphasize sensitivity to local conditions when conducting financial contributions and practicing political divestiture in different cultural contexts. Financial executives with foreign subsidiaries should gain training to adapt to specific sustainable development needs and circumstances of local sustainability customs to address sustainable development meaningfully.

In the international arena, external influences have shaped the practice of Financial Social Responsibility. National legislations, policy frameworks and cultural landscapes have brought out differing SRI forms as governmental forces and institutional incentives either curb or perpetuate specific financial social considerations. With no stringent legal international basis, in some parts of the world, SRI activities are mandated by national, federal, state or local laws and regulations. In others, the judicial record leaves room for investors if and how to allocate resources in a socially conscientious way. Until today our insights on external forces shaping SRI customs, however, remain rudimentary. SRI practices are still inconclusive in the global arena leading to disparate SRI notions throughout the world. Capturing the current state of SRI around the world will give a more conclusive picture of the role of Financial Social Responsibility for sustainable development. Analyzing financial social considerations on a global scale through a prism of legal setting and institutional customs will help finding mutually-shared contents of financial social investment. Paying attention to international differences of SRI options will also serve as a first step to harmonize differing Financial Social Responsibility practices in the ongoing SRI adaptation around the globe. Enabling a more harmonious discourse on SRI will reduce the complexity of SRI and diminish socio-economic losses imbued in the ambiguity of this multi-stakeholder phenomenon. Studying the manifold SRI expressions resulting from the various interplays of governmental, corporate and financial market forces will also allow drawing inferences about a positive political divestiture framework and boundary conditions of financial social conscientiousness for sustainable development. International SRI descriptions will thus offer insights on Financial Social Responsibility triggers and repeatable patterns as a basis for successful SRI policies for sustainable development. Another possibility would be to develop new approaches to international investment law and policymaking for promoting sustainability and inclusive development.

When investigating the role of the finance sector in sustainable development, a holistic viewpoint on Financial Social Responsibility must be taken. Innovatively coupling individual decision making research findings' with insights on external influences on social responsibility promises to help managing financial market social responsibility risks for society. While micro-behavioral economists may in particular unravel human socially responsible cognition in the search for human-imbued ethicality nudges; macro-economists may explain how individual social responsibility can shape collective market outcomes.

General investigations of the perception of SRI in the wake of the inception of the SDGs could determine in what way the financial crisis has changed the financial community's view of economic markets' social responsibility obligations. Once-in-a-century-available information on the social representations of financial social conscientiousness in the time of climate change action should be reaped as a unique source on societal perceptions of financial market reforms for a pro-active stakeholder engagement. Studying investors' cognition on SRI in this unique transition point in time also provides an innovative snapshot of the current crises' 
potentials to ingrain ethicality in competitive market systems.

Concurrent multi-stakeholder analyses may attribute the newly-defined role of public and private constituents in social contributions and search for the optimum balance of deregulated market systems and governmental control in providing sustainable development. Capturing real-market social responsibility phenomena could thereby not only help finding well-tempered public-private partnership networks to support sustainable development. Oversight accountability could also present information on corporate and financial social conduct that will lead academics, technocrats and practitioners to reflect deeper about responsibility within market systems and rethink their roles in backing socially-favorable finance flows.

While ingraining social conscientiousness in financial market appears as a panacea to avert future economic crisis, behavioral economists may contribute their insights on the human natural laws of social responsibility (Puaschunder, 2012). Behavioral ethics specialists may inform on the role of political and financial decision making for sustainable development. Behavioral economics laboratory experiments could thereby shed light on human ethicality to help reducing cognitive barriers on moral dilemmas and alleviate potential financial-social decision making predicaments (Puaschunder, 2012).

Evolutionary psychologists may explore the emergence of ethicality in human beings by investigating what aspects of social responsibility are ingrained in human traits and the constitution of mind and which ones are nurtured by external factors. Organizational behavior scholars may add by attributing how goals can stipulate ethicality in the finance world. Unpacking social responsibility incentives but also goal settings with positive externalities appear as interesting research avenues. In the case of financial markets, short-term goals can lead to critically trade-off from long-term societal endeavors (Puaschunder \& Schwarz, 2012; Shilon, 2011). Future research on the fallibility of human decision makers and external, global influences on social responsibility may help deriving recommendations on how to steer socially conscientious behavioral patterns in the finance world. All these endeavors are aimed at fostering Financial Social Responsibility as a future guarantor of economic stability and sustainable social progress throughout the world. This piece hopefully contributes to a future rise of social responsibility in our currently globalizing, economically-transforming and environmentally-fragile world, in which we should feel responsible.

The newly emerging CSR and SRI phenomena also open avenues for future research on social responsibility trends. Academic institutions should nurture the financial community's ethical sense. Business schools and think tanks could support SRI research and offer financial ethics education. Financial economists are advised to integrate socio-economic factors into standard economic profit maximization models. Concurrently behavioral economists should aim at explaining human decisions making fallibility on responsibility considerations and ethicality perceptions.

Future research may study SRI in a qualitatively and quantitatively nested approach. Qualitative interviews on the social perception of SRI will help resolving societal losses imbued in the novelty of the phenomenon and aligning incoherent viewpoints on SRI. Exploratory studies may capture predicted SRI trends with attention to socio-economic success factors of Financial Social Responsibility and stakeholder-specific SRI nuances. Quantitative market assessments may feature the event study methodology as the state-of-the-art analysis technique for capturing the impact of political divestiture with a sustainable development focus on corporate success. Financial market experiments may complementary test microeconomic effects of divestment behavior. Research on bounded decision making could reveal implicit and accidental financial social irresponsibility and may validate socio-psychological SRI motives to distinguish moderator variables of investors' willingness to trade off financial profits for social gratifications (Puaschunder, 2011b). The findings will reduce cognitive barriers of decision making predicaments and lead to educative means for steering behavioral patterns in a more socially conscientious direction. Research-based transparency campaigns could promote political divestiture as a more risk-free market option during times of crisis throughout the financial community and thereby raise the stakeholders' confidence in pro-social political divestiture sustainable development.

The role of supranational factors that influence responsible leader behavior provide further insight into the propensity to engage in sustainable development. With supranational institutions - such as the UN-having turned to the codification of the triple bottom line in the UN Global Compact, managers are increasingly respected for their accountability and responsibility. Insights on the influence of supranational regulatory measures and institutions (e.g., NGO activism and the enactment of the UN Global Compact) on financially-responsible managerial behavior may shed light on success factors in the adoption of sustainable development in the finance world. International institutions should set priorities on the political divestiture for sustainable development implementation agenda. Quantitative metrics based on standardized evaluation 
frameworks could help coordinate a global monitoring and impact assessment of the role of the finance sector in the sustainable development implementation. The IMF conditionalities could serve as a role model for lasting sustainable development impact and the positive funds allocation monitoring and due diligence quality assurance. In additions, indices of local, national, regional and global financial sustainability endeavor will help build public private partnership synergies but also shed light on positive and negative externalities and trade-offs of political divestiture steering sustainable development. Independent governance institutional evaluation frameworks will help streamline social, economic and environment goals through cost-benefit analysis, life cycle cost discounting and social equality programs. Public private partnerships will aid the adaptability and flexibility in collaborations between governments, the finance sector and academia. International organizations' emergent risk and crises prevention frameworks will help reform political divestiture endeavors to imbue a sustainability focus and how multiple actors' divestiture strategies could be streamlined and synchronized. Differences in business systems, legal context, the nature of regulation and likelihood of enforcement and punishment modes therefore have to be scrutinized when shaping the political divestiture agenda in the global arena.

Academic research can aid to spearhead temporal perspectives in contemporary SRI research. In particular, a macroeconomic model of political divestiture impacts over time could study intertemporal transfers from the finance sector to sustainable development with special attention to public and private sector contributions as well as benefit and burden sharing (Puaschunder, 2015b). Based on the triple bottom line, social, environmental and economic sustainable development contribution potentials of the finance world could be explored. Cross-cultural differences could be outlined by cross-sectional regression analyses on a global scale.

Avenues of future research could also enhance our understanding of how the finance world and other stakeholders can effectively promote socially responsible behavior for sustainable development. A wider conceptualization of political divestiture leadership based on comparative cross-cultural research will help detect sustainable development antecedents. Interdisciplinary, multilevel research will allow outlining drivers of sustainable development in the investment community and situational influence factors on sustainable development in the international financial sector. The organizational, situational, societal, and supranational-level determinants of responsible financial managerial behavior can be influenced by top management teams, policy makers, educators, and external regulators. Best practice studies in this area could shed light on how financial companies can systematically design and utilize human resource management practices and leadership development programs to promote responsible investment behavior. Prospective findings may thus enhance our understanding of how finance companies and other stakeholders can effectively prevent, manage and control the finance sector risks associated with politically fragile markets but also go beyond to explore innovative ways how SRI can contribute to sustainable development around the globe. Capturing the impact of external factors on financial socially responsible decision making and coping with the ethical dilemmas in leadership challenges may serve as a basis for training and development activities on using political divestiture for accomplishing positive societal change. The implementation of political divestiture for sustainable development could further be solicited through building financial cultures that enhance an ethical climate.

In line with the mere exposure effect, access to information on sustainable development fosters the integration of environmental and social governance in financial decision making (Frey \& Irle, 2002). Information disclosure about the stability and effectiveness of political divestiture when attributed to sustainable development will help driving consumer confidence in pro-social political divestiture acts. With the rising importance of transparent Financial Social Responsibility and financial institutions integrating social, environmental and governance issues into investment analysis; social investment criteria should become a standard part of the fiduciary duty of trustees, financial advisers, asset managers and intermediary institutions. To strengthen these trends, financial institutions and experts are encouraged to consider environmental and social responsibility in a variety of ways. Information on positive political divestiture should become part of financial market operations. Media reports may inform asset managers and financial analysts about the link between political divestiture and sustainable development. Supervisory bodies could help promote the inclusion of socio-ethical political criteria in financial management. Accounting entities, rating agencies and index providers should adopt environmental and social governance standards as a basis for evaluation criteria that guarantee the concurrent financial and ethical performance. Stock exchange advisors can help by communicating listed corporations the importance of environmental and social responsibility governance. Asset managers should encourage brokers to conduct SRI screenings with a political and sustainable development focus. Investors are recommended to request information on SRI and develop political proxy voting strategies. Pension fund trustees can help by considering environmental and social criteria in the formulation of investment mandates. Consultants and financial advisers 
should incorporate environmental and social corporate governance in their portfolio allocation strategies and accept social responsibility as a state-of-the-art of fiduciary obligations. Financial analysts will then assess market opportunities with respect for social contributions and actively participate in ongoing voluntary responsibility initiatives. As the basis for stakeholder engagement and monitoring, transparency and accountability are key for advancing corporate and financial social market behavior. Novel SRI options that fulfill unmet responsibility needs will open the market for socially responsible economic growth whilst bringing societal change.

Future research may also connect the individual experience to social responsibility in order to unravel ethicality nudges. Common goal compliance is hoped to be modeled by contexts that automatically nudge corporate decision makers in a sustainable development direction. Internationally validated political divestiture for sustainable development models will elucidate intercultural, national and regional differences on sustainable finance impact. Findings will help imbue efficiency measures on political divestiture for sustainable development through real-world relevant means following the greater goal to provide fruitful corporate contributions for a sustainable mankind. Cross-national sustainability solutions and interculturally-sensitive political divestiture business practices may help imbue sustainable development concern in corporate conduct in the global arena.

On the financial corporate incentive level, sustainable development may be implemented through performance management and reward systems to hold managers accountable for politically irresponsible behavior as well as create psychological incentives to think about future consequences of current corporate conduct and financial support of irresponsible markets. Best practices studies on political divestiture will serve as corporate risk management tool to help build a culture of positive SRI and foster a corporate design that pays tribute to ethical financial leadership. In building a cadre of sustainable development leaders in the finance world through corporate trainings and team building development but also Financial Social Responsibility performance measurement and political-conscientious decision making reward systems, sustainable development in the finance sector will be advanced.

At the organizational level, when recruiting, selecting and promoting financial managers, it is essential for organizations to understand how individual-level variables such as personality traits, motives and values may predict managers' propensity to engage in ethical behavior. For example, firms can use personality tests and integrity tests, along with interviews and assessment centers, to help determine which employees might be more likely to act politically responsibly. They can also assess applicants' attitudes and values to decide whether they will match the corporate culture, with the assumption that candidates' formal qualifications and job-related skills may not be the best predictors of responsible behavior on the job. Studying personality traits but also motives and values that steer financial managers' propensity to engage in politically-conscientious financial decision making will allow to set up assessment centers that reveal which individuals are more likely to act irresponsibly and if the managerial ethics will likely match the corporate culture on the sustainable development dimension.

Sustainable development can also be imbued in financial activities by creating and enforcing financial company policies and codes of conduct, supporting training and development initiatives which are aimed at increasing moral awareness regarding political conditions of the operating markets. Once the individual has joined the organization, induction programs, individual coaching by the supervisor, training and development programs, and other socialization practices could ensure that newcomers learn values, expected behaviors, and social knowledge that are necessary to become politically conscientious financial managers and leaders. In terms of communication and control systems, top management teams and governmental officials may actively promote responsible behavior and discourage irresponsible behavior by communicating ethical integrity messages.

Regarding the specific case of political divestiture, future behavioral decision-making studies may target at unravelling the decision to divest, asking whether corporations were pressured into divestment by shareholders, customers or other stakeholders. First-mover advantage effects may be investigated alongside general SRI questions such as the authenticity of divestiture. Future investigations may also pay attention to the generalisability of former punishment political divestiture cases such as the divestiture from Sudan, capital flight from Burma, the ongoing capital drain from Iran, the arms embargo of the Israel-Palestine region and the contemporary trend towards positive political divestiture fossil fuel divestment and reallocation towards green funds. Special attention could be paid to developing countries which are most dependent on FDI for aid and especially vulnerable to political infringements, humanitarian crises and sustainable development needs. Comparison studies with different divestment sectors could allow the derivation of a common theory on the corporate implications of divestiture and financial impact in accomplishing sustainable development goals. 


\section{Conclusion}

In conclusion, this article intended to help resolve the questions that emerge from political divestiture's role for sustainable development. In the age of sustainable development, the demand for ingraining ethicality in financial decision making has reached unprecedented momentum. Overall, the paper explored innovative corporate and financial market potentials to create value for society. A political divestiture for sustainable development framework portrayed the manifold potentials of political divestiture to finance sustainable development in a harmonious interplay of deregulated market systems and governmental control in ensuring market-driven social responsibility. Future research may address ways how to better capture the effects of political divestiture on economic markets and societal systems in order to provide recommendations for a successful rise of sustainable development solutions within modern market economies. All these endeavors are aimed at fostering Financial Social Responsibility as a future guarantor of sustainable economic stability and societal progress throughout the world.

\section{Acknowledgements}

Financial support of the Fritz Thyssen Foundation, the Eugene Lang Liberal Arts College of The New School, the New School for Social Research, the Tishman Environment and Design Center, and the University of Vienna is gratefully acknowledged. The author declares no conflict of interest. The author thanks Professor Lez Rayman-Bacchus and the participants of the $3^{\text {rd }}$ International Symposium on Corporate Responsibility \& Sustainable Development staged at Toronto, Canada, in June 2015 for most valuable intellectual stimulation and helpful feedback. All omissions, errors and misunderstandings in this piece are solely the author's.

\section{References}

Ahmad, M. (2008). Global CEOs at World Economic Forum cite sovereign wealth funds as the new power broker. BI-ME, January 24, 2008.

Alperson, M., Tepper-Marlin, A. T., Schorsch, J., \& Wil, R. (1991). The better world investment guide: One hundred companies whose policies you should know about before you invest your money. Prentice Hall: New York.

Beck, U. (1998). Wie wird Demokratie im Zeitalter der Globalisierung möglich? In U. Beck (Ed.), Politik der Globalisierung. Frankfurt am Main: Suhrkamp.

Bekefi, T. (2006). Business as a partner in tackling micronutrient deficiency: Lessons in multisector partnership. Report of the Corporate Responsibility Initiative. Cambridge, MA: Harvard University Press.

Biller, A. (2007). Socially responsible investing now part of the landscape. Benefits \& Compensation Digest, 44, 12.

Broadhurst, D., Watson, J., \& Marshall, J. (2003). Ethical and socially responsible investment: A reference guide for researchers. Saur: München.

Butz, Ch. (2003). Decomposing SRI performance: Extracting value through factor analysis. Pictet Quants, September 2003.

Centeno, M. A., \& Tham, A. (2012). The emergence of risk in the global system. Unpublished working paper. Princeton University.

Dittmar, A., \& Shivdasani, A. (2003). Divestitures and divisional investment policies. Journal of Finance, 58(6), 2711-2743. http://dx.doi.org/10.1046/j.1540-6261.2003.00620.x

Dixon, F. (2002). Financial markets and corporate environmental results. Working paper, Innovest.

Elkington, J. (1997). Cannibals with forks: The triple bottom line of twenty-first century business. Oxford: Capstone.

Fitzgerald, N., \& Cormack, M. (2007). The role of business in society: An agenda for action. Retrieved from http://www.hks.harvard.edu/mrcbg/CSRI/publications/report12

Frey, D., \& Irle, M. (2002). Theorien der Sozialpsychologie. Bern: Hans Huber.

Friedman, M. (1970). The social responsibility of business is to increase its profits. New York: The New York Times.

Grunberg, L. (1981). Failed multinational ventures: The political economy of international divestments. Lexington Books: Lexington, MA.

Hamilton, S., Hoje, J., \& Statman, M. (1993). Doing well while doing good? The investment performance of 
socially responsible mutual funds. Financial Analysts Journal, 49(6), 62-66. http://dx.doi.org/10.2469/faj.v49.n6.62

Harrigan, K. R. (1981). Deterrents to divestiture. Academy of Management Journal, 24(2), 306-323.

Harvey, C. (2008). Campbell R. Harvey's hypertextual finance glossary. Retrieved from http://www.duke.edu/ charvey/Classes/wpg/bfglosa.htm.

Jones, S., van der Laan, S., Frost, G., \& Loftus, J. (2008). The investment performance of socially responsible investment funds in Australia. Journal of Business Ethics, 80(2), 181-203. http://dx.doi.org/10.1007/s10551-007-9412-6

Kanter, R. M. (2003). From spare change to real change. Harvard Business Review on Corporate Responsibility, Harvard Business School, Cambridge, MA.

Little, K. (2008). Socially responsible investing: Put your money where your values are. New York: Penguin.

Livesey, S. (2002). The discourse of the middle ground: Citizen Shell commits to sustainable development. Management Communication Quarterly, 15, 313-349. http://dx.doi.org/10.1177/0893318902153001

Mackey, A., Mackey, T., \& Barney, J. (2004). Corporate social responsibility and firm performance: Investor preferences and corporate strategies. Working paper Retrieved from http://www.sristudies.org/Mackey+et+al+(2004)

Matten, D., \& Crane, A. (2005). Corporate citizenship: Toward an extended theoretical conceptualization. Academy of Management Review, 30, 166-179. http://dx.doi.org/10.5465/AMR.2005.15281448

McCann, L., Solomon, A., \& Solomon, J. F. (2003). Explaining the growth in U.K. socially responsible investment. Journal of General Management, 28(4), 15-36.

McLachlan, J., \& Gardner, J. (2004). A comparison of socially responsible and conventional investors. Journal of Business Ethics, 52(1), 11-25. http://dx.doi.org/10.1023/B:BUSI.0000033104.28219.92

McWilliams, A., \& Siegel, D. (2000). Corporate social responsibility and financial performance: Correlation or mis-specification? Strategic Management $\quad$ Journal, $603-609$. http://dx.doi.org/10.1002/(SICI)1097-0266(200005)21:5\%3C603::AID-SMJ101\%3E3.0.CO;2-3

McWilliams, A., Siegel, D., \& Teoh, S. W. (1999). Issues in the use of the event study methodology: A critical analysis of corporate social responsibility studies. Organizational Research Methods, 2, 340-365. http://dx.doi.org/10.1177/109442819924002

Merriam Webster Dictionary. (2008). Retrieved from http://merriam-webster

Mohr, L. A., \& Webb, D. J. (2005). The effects of corporate social responsibility and price on consumer $\begin{array}{lllll}\text { responses. Journal of Consumer } & \text { Affairs, } & 39(1), & 147 .\end{array}$ http://dx.doi.org/10.1111/j.1745-6606.2005.00006.x

Mohr, L. A., Webb, D. J., \& Harris, K. E. (2001). Do consumers expect companies to be socially responsible? The impact of corporate social responsibility on buying behavior. Journal of Consumer Affairs, 35(1), 45-72. http://dx.doi.org/10.1111/j.1745-6606.2001.tb00102.x

Nelson, J. (2004). Leadership, accountability and partnership: Critical trends and issues in corporate social responsibility. Report of the Corporate Responsibility Initiative. Cambridge, MA: Harvard University.

Panitch, L., \& Gindin, S. (2012). The making of global capitalism: The political economy of American empire. New York: Verso.

Puaschunder, J. M. (2010). On corporate and financial social responsibility. Unpublished Doctoral Thesis. University of Vienna, Faculty of Psychology.

Puaschunder, J. M. (2011a). On the emergence, current state and future perspectives of Socially Responsible Investment. Harvard University Weatherhead Center for International Affairs Working Paper. Retrieved from

http://wcfia.harvard.edu/publications/emergence-current-state-and-future-perspectives-socially-responsibleinvestment

Puaschunder, J. M. (2011b). Socio-psychological motives of socially responsible investors. Harvard University Weatherhead Center for International Affairs Working Paper. Retrieved from http://wcfia.harvard.edu/publications/socio-psychological-motives-socially-responsible-investors 
Puaschunder, J. M. (2012). Ethical decision making under social uncertainty: An introduction to Überethicality. Harvard University Faculty of Arts and Sciences Working Paper. Cambridge, MA: Harvard University.

Puaschunder, J. M. (2013). Ethical investing and socially responsible investing. In K. H. Baker \& V. Ricciardi (Eds.), Investor Behavior. New York: John Wiley \& Sons Finance Series.

Puaschunder, J. M. (2015a). Global responsible intergenerational leadership: The quest of an integration of intergenerational equity in Corporate Social Responsibility (CSR) models. The New School for Social Research Department of Economics Working Paper. New York: The New School.

Puaschunder, J. M. (2015b). Intergenerational transfers model. The New School for Social Research Department of Economics Working Paper. New York: The New School.

Puaschunder, J. M. (2015c). On the social representations of intergenerational equity. Oxford Journal of Finance and Risk Perspectives, 4(4), 78-99.

Puaschunder, J. M. (2015d). When investors care about politics: A meta-synthesis of political divestiture studies on the capital flight from South Africa during Apartheid. Business, Peace and Sustainable Development, 5(24), 29-52. http://dx.doi.org/10.9774/GLEAF.8757.2015.ju.00004

Puaschunder, J. M. (forthcoming). Socially Responsible Investment (SRI) as emergent risk prevention and means to imbue trust in the post 2008/09 World Financial Crisis economy. The Routledge Handbook of Social and Sustainable Finance. London: Routledge.

Puaschunder, J. M., \& Schwarz, G. (2012). The future is now: How joint decision making curbs hyperbolic discounting but blurs social responsibility in the intergenerational equity public policy domain. The Situationist. Harvard University Law School Project on Law and Mind Sciences working paper http://dx.doi.org/10.2139/ssrn.2027189

Scholte, J. A. (2000). Globalization: A critical introduction. Basingstoke: Palgrave.

Schueth, S. (2008). Socially responsible investing in the United States. Journal of Business Ethics, 4, 189-194.

Shilon, N. (2011). Illusory equity holding policies. Unpublished working paper, Harvard Law School.

Sparkes, R. (2002). Socially responsible investment: A global revolution. Cronwall: Wiley.

Sparkes, R., \& Cowton, Ch. J. (2004). The maturing of socially responsible investment: A review of the developing link with corporate social responsibility. Journal of Business Ethics, 52, 45-57. http://dx.doi.org/10.1023/B:BUSI.0000033106.43260.99

Starr, M. (2008). Socially responsible investment and pro-social change. Journal of Economic Issues, 42(1), 51-73. http://dx.doi.org/10.1080/00213624.2008.11507114

Steurer, R. (2010). The role of governments in corporate social responsibility: Characterizing public policies on CSR in Europe. Policy Science, 43, 49-72. http://dx.doi.org/10.1007/s11077-009-9084-4

Tippet, J. (2001). Performance of Australia's ethical funds. Australian Economic Review, 34(2), 170-178. http://dx.doi.org/10.1111/1467-8462.00186

Trevino, L. K., \& Nelson, K. A. (2004). Managing business ethics: Straight talk about how to do right. Hoboken: Wiley.

Werther, W. B., \& Chandler, D. (2006). Strategic corporate social responsibility: Stakeholders in a global environment. Thousand Oaks: Sage.

Williams, G. (2005). Are socially responsible investors different from conventional investors? A comparison across six countries. Unpublished working paper, University of Bath. http://dx.doi.org/10.2139/ssrn.905187

Wolff, M. (2002). Response to "Confronting the critics." New Academy Review, 1, 230-237.

World Investment Report. (2015). Reforming international investment governance. United Nations Conference on Trade and Development Report. New York: United Nations.

Zeff, E., \& Pirro, E. (1999). Redistribution of authority: The South African case. International Studies Association, Washington, DC.

Zoellick, R. (2009). Time to herald the Age of Responsibility. The Economist, 17 January. Retrieved from www.ft.com/cms/s/o/1348d34e-ebod-iidd-bb6e-0000779fd2ac.html\#axzz3ZTB8qYsL 


\section{Copyrights}

Copyright for this article is retained by the author(s), with first publication rights granted to the journal.

This is an open-access article distributed under the terms and conditions of the Creative Commons Attribution license (http://creativecommons.org/licenses/by/3.0/). 